\title{
Litigating the Limits of Religion: Minority and Majority Concerns about Institutional Religious Liberty in India
}

\author{
Chad M. Bauman
}

check for updates

Citation: Bauman, Chad M.. 2021. Litigating the Limits of Religion: Minority and Majority Concerns about Institutional Religious Liberty in India. Religions 12: 400. https:// doi.org/10.3390/rel12060400

Academic Editors: Timothy Shah and Nathan A. Berkeley

Received: 18 April 2021

Accepted: 28 May 2021

Published: 31 May 2021

Publisher's Note: MDPI stays neutral with regard to jurisdictional claims in published maps and institutional affiliations.

Copyright: (C) 2021 by the author. Licensee MDPI, Basel, Switzerland. This article is an open access article distributed under the terms and conditions of the Creative Commons Attribution (CC BY) license (https:/ / creativecommons.org/licenses/by/ $4.0 /)$.
Department of Philosophy, Religion, and Classics, Butler University, Indianapolis, IN 46208, USA; cbauman@butler.edu

\begin{abstract}
Western religious liberty advocates tend to focus on restrictions placed on minority religious communities, particularly when advocating abroad, that is, outside of the country in which they reside. In all contemporary democracies, however, adherents of religious majorities also express concerns about religious liberty. For this reason, the article considers both minority and majority concerns about institutional religious freedom in India. This essay provides an overview of religious freedom issues, with a particular focus on institutions, though, as I acknowledge, it is not always simple to distinguish individual from institutional matters of religious freedom. After describing various minority and majority concerns about institutional religious freedom in India, and demonstrating that many of them are related to the Indian government's distinctive approach to managing religion and religious institutions, I make the argument that while some cross-cutting issues provide the possibility of interreligious understanding and solidarity in matters of religious liberty advocacy, such solidarity will not emerge without considerable effort because of the fact that debates about religious liberty in India often fundamentally involve debates about the very nature of religion itself, and these debates tend to divide rather than unite India's majority and minority religious communities.
\end{abstract}

Keywords: Hindu; Christian; law; restriction; religion; religious freedom; India; minority; majority; legal; regulation; temples; churches; mosques

\section{Introduction}

Western religious liberty advocates tend to focus on restrictions placed on minority religious communities, particularly when advocating abroad, that is, outside of the country in which they reside. In all contemporary democracies, however, adherents of religious majorities also express concerns about religious liberty. For this reason, this article considers both minority and majority concerns about institutional religious freedom in India. The inclusion of both minority and majority concerns and demands should not be construed as an assertion of their equal legitimacy or their logical or moral equivalence, nor as an implicit argument that the existence of both minority and majority concerns about religious liberty demonstrates that minority and majority interests have been appropriately balanced in Indian law and society. However, by attending to both majority and minority concerns, it is possible to foreground the fact that while, in most cases, religious minorities (and/or minorities within the majority) are more thoroughly targeted by religious liberty restrictions, such restrictions often end up infringing upon the freedoms of religious majorities as well.

This is an important point in India, where majoritarian politics are on the rise, and where there therefore seems little possibility of minority-majority solidarity on matters of religious liberty. Acknowledging that the religious majority also has concerns about religious liberty, however, may help those who care about religious freedom more generally to gain a hearing in majority circles, and therefore-waxing idealistic - to more effectively promote minority-majority solidarity and mutual understanding.

Because of the thematic focus of this special issue, this essay provides an overview of religious freedom issues, with a particular focus on institutions, though, as I acknowledge, 
it is not always simple to distinguish individual from institutional matters of religious freedom. With one possible exception (that of the Uniform Civil Code/personal laws discussed briefly in the conclusion), the cases highlighted are those that have generated by far the most national, and even international discussion and debate over the last two decades. After describing various minority and majority concerns about institutional religious freedom in India, and demonstrating that many of them are related to the Indian government's distinctive approach to managing religion and religious institutions, I make the argument that while some cross-cutting issues provide the possibility of interreligious understanding and solidarity in matters of religious liberty advocacy, such solidarity will not emerge without considerable effort because of the fact that debates about religious liberty in India often fundamentally involve debates about the very nature of religion itself. These debates tend to divide rather than unite India's majority and minority religious communities.

\section{Context}

There is a long and impressive history of interreligious tolerance in India, one promoted by Indian rulers at least as far back as the third-century BCE emperor, Ashoka the Great, whose rock edicts famously declared his respect for all sects and counseled his subjects to avoid disparaging others' religious beliefs. The Indian tradition of tolerance has often manifest in a willingness to consider others' religious beliefs "true," but inferior, and only in subordination to the higher truths of one's own tradition, which is why Ainslee Embree (1990, p. 25) referred to it as "encapsulation" rather than "tolerance," adding that encapsulation was "neither toleration, absorption, nor synthesis." Nevertheless, it has also produced, historically speaking, a relatively remarkable degree of interreligious harmony.

Such ideals were promoted at independence by India's most influential political intellectuals, Jawaharlal Nehru (1889-1964), Sarvepalli Radhakrishnan (1888-1975), and Mohandas K. ("Mahatma") Gandhi (1869-1948). Hindu ideals tinctured independent India's conception of secularism, but that is of course to be expected, since the construction of Western secularism was certainly inflected by Christian ideals as well. Gandhi's views on secularism and religious freedom were in fact quite complex. On the one hand, he sought interreligious solidarity, regularly admitted to finding wisdom and truth in other religious traditions, approached all political challenges with admirable equilibrium, and was committed to non-violence. On the other hand, Hindu voices and symbolism dominated the independence movement that he led, he periodically betrayed majoritarian instincts, and his conception of the purpose of religion itself-as spiritual advance and transformation available within any religious tradition - clearly emerged from the "Indic" religious milieu that included Hinduism, Buddhism, Jainism, and Sikhism, such that he found proselytization ${ }^{1}$ uncouth and unreligious, and periodically declared his support for banning it (Claerhout 2010, 2014). (Note here, for the sake of the conversation below, how a particular conception of religion inherently recommends a particular politics in terms of the management of religion.)

As is clear from the discussion above, then, through much of the long arc of its history, and even long before its modern democratization, India has enjoyed the presence of the "twin tolerations" that Alfred Stepan (2001) famously argued were so critical to the functioning of democratic society, i.e., the "toleration of religious citizens ... [to] accord democratically elected officials the freedom to legislate and govern without having to confront denials of their authority based on religious claims," and the willingness of government laws and officials to "permit religious citizens, as a matter of right, to freely express their views and values within civil society, and to freely take part in politics, as long as religious activists and organizations respect other citizens' constitutional rights and the law" (Stepan 2012, p. 90). Though there have been paroxysms of massive interreligious violence in India, the region's political and legal structures have traditionally respected the distinction between political and religious leadership and promoted interreligious tolerance while still allowing for the substantive, even clamorous inclusion of religious 
viewpoints in public affairs. Moreover, while independent India has periodically moved to regulate or repress Hindu nationalist organizations like the Rashtriya Swayamsevak Sangh, there have been no appearances of the thoroughly religiously repressive secularist regimes found, for example, in communist states, or in late eighteenth-century France, or the Middle East from the late nineteenth to the early twentieth centuries. Nor have there been theocratic movements of any power or endurance.

Still, already in 2009, long before 2014, when India's Hindu nationalist Bharatiya Janata Party (BJP) won the first of its two successive national elections, increasing issues with regard to religious freedom had led Pew to rank India as a country with a "high" level of government restrictions on religion (the second highest ranking), and a "very high" level of social hostilities related to religion (the highest possible ranking). In Pew's most recent report (published in 2020, using 2018 data), only nine other countries were judged to have "very high" levels of social hostility. ${ }^{2}$ In addition, according to Pew, among the world's 25 most populous countries, India joined Egypt, Indonesia, Pakistan, and Russia as the five with the highest overall levels of both government restrictions and social hostilities involving religion (Pew Research Center 2020, p. 39). Similarly, in its 2020 report, the United States Commission on International Religious Freedom (USCIRF) placed India, for the first time, on its list of "Countries of Particular Concern" (United States Commission on International Religious Freedom 2020). ${ }^{3}$ India's woes are arguably overstated, in part by Pew's emphasis on raw numbers rather than numbers adjusted for population, and even USCIRF Commissioner, Gary Bauer, dissented from his Commission's findings. Still, such reports highlight significant issues with regard to religious liberty in India.

The rise of majoritarian politics in contemporary India, however, threatens the endurance of the twin tolerations yet further. In recent years, the rights of Muslims and Christians to freely express their views in the social and political sphere have been increasingly curtailed through both legal means and social repression. The justification given for this progressive curtailment is that Islam and Christianity, using Stepan's language, do not "respect other citizens' constitutional rights and the law." To understand this claim, one must remember that Indians have historically "encapsulated" rather than rejected others' religions (as described above). From the perspective of Ashoka's ancient advice to avoid unnecessarily disparaging others' religions and this historically dominant tradition of encapsulation, traditions that demonize or denounce other religions (as more exclusivistic versions of Islam and Christianity sometimes do) appear inherently intolerant, and appear also to deny others' constitutional right to freedom from religious insult and critique. And if they do (again from this particular perspective), then the government has no obligation (and in fact would be ill-advised) to tolerate them. While many therefore blame the rise of Hindu nationalists for the decline of India's twin tolerations, Hindu nationalists themselves would justify their withholding of toleration from Islam and Christianity on the grounds that those religions threaten India's tradition of religious tolerance itself.

It is for good reason, then, that there is currently a pitched rhetorical and ideological battle over Gandhi's historical legacy. And while this battle concerns history, it is in reality more about the future, that is, about the right to determine the shape of Indian society, and in particular the relationship of its religious communities one to another. This battle pits more pluralist and pro-minority individuals, institutions, and political parties against their more Hindu majoritarian counterparts. Both claim Gandhi's mantle, and both are, in a partial sense, Gandhi's rightful heirs. Both, moreover, embrace the term "secular," though they understand the term in radically different ways. While for much of India's independent history, those in the former group enjoyed political power, in the last two decades, and especially since 2014, those in the latter group have been ascendant. This ascendancy, and the continuing tension between these two visions of and for India, animate and give contemporary Indian debates and controversies over religious liberty their distinctive flavor.

What should be clear from the previous paragraph is that the complexity of Gandhi's views on religion, religious freedom, and secularism are mirrored in the views of the 
citizens of the nation he helped found, as well as in its constitution and laws governing religion. Article 25 of the Indian Constitution guarantees that "all persons are equally entitled to freedom of conscience and the right to freely profess, practice, and propagate religion subject to public order, morality and health." In addition, since 1976, India has identified itself as a "sovereign, socialist secular democratic republic." These significant statements clearly enshrine the basic principles of religious freedom in Indian law. When minority and majority concerns about religious freedom arise in contemporary India, therefore, they are generally related not to constitutional provisions in and of themselves but rather to the following:

1. The interpretation of constitutional provisions (e.g., on the term "propagate");

2. Failure to implement constitutional directives (e.g., on a Uniform Civil Code);

3. Statutory laws or judicial rulings that appear to privilege the majority Hindu community or target/disprivilege a specific minority religious community (e.g., the Citizenship Amendment Act, or state "Freedom of Religion" laws);

4. The use of statutory law as a tool of harassment (e.g., state "Freedom of Religion" and anti-blasphemy laws);

5. Government management of institutional religious affairs (e.g., temple management boards, restrictions on foreign funding);

6. Extrajudicial suppression of constitutionally enshrined freedoms through acts of vigilante justice and/or intimidation (e.g., cow vigilantism, anti-love jihad crusades, anti-minority violence);

Each of these is discussed, in one way or another, in the pages that follow.

\section{Minority Concerns}

If this article were focused on matters of religious freedom more generally, it would naturally discuss recent controversies about the Citizenship (Amendment) Act of 2019 (CAA), the troubling increase in "cow vigilantism" (attacks on those suspected of beef consumption or trade), or mob lynching related to the bogeyman of "love jihad" (Adcock 2010, pp. 297-311; 2018, pp. 340-54; Engineer et al. 2020; Mehta 2019a; Rao 2011, pp. 80-87; Wilkes and Srivastava 2017). These matters primarily concern Muslims, since (along with Dalits in the case of cow vigilantism) Muslims are most affected by them. It is certainly the case that in the aggregate, suppression of individual religious freedoms can have a negative effect on institutional religious freedom as well. However, this article focuses on issues of clear and explicit institutional relevance. These are organized below into sections focusing on the respective concerns of India's minority and majority religious communities (though as discussed in the conclusion, the division into minority and majority concerns requires something of an oversimplification).

\subsection{Restrictions on Religious Assembly}

A matter of contemporary concern relevant to freedom of religious assembly is the government's revocation of Article 370 on 5 August 2019. Article 370 of the Indian Constitution assigned to the state of Jammu and Kashmir (J\&K) limited autonomy to have its own constitution and make its own laws regarding ownership of property, fundamental rights, etc. Critics claimed that the state's special status prevented its economic development (e.g., through laws preventing other Indians from owning land in the state) and also hampered the government's efforts to root out radical Islam and terrorist infiltration from Pakistan (J\&K was the only Indian state with a Muslim majority, and Pakistan still claims significant sections of the territory as its own).

The revocation of J\&K's special status had long been a stated goal of the BJP, and it was a prominent plank of the party's 2019 re-election platform. After its decisive victory in that election, the BJP government quickly moved in extra troops to squelch predictable unrest, revoked Article 370, and effectively shut down many of the region's institutional infrastructure by simultaneously invoking Section 144 of the Criminal Code of Procedure. Under Section 144, the government limited public movement and assembly, arrested 
opposition party leaders, shut down the internet, closed down mosques, and detained at least a few Muslim clerics, while threatening others with imprisonment should they publicly criticize the central government's actions (Mehta 2019b; Scroll Staff 2019; Zargar 2019). The government argued that these restrictions were necessary to preserve law and order, but many Muslims considered them a targeted assault on their religious freedom.

A year on, many of the restrictions and detentions remain in effect, some now justified on the grounds of preventing the spread of COVID-19. Existing restrictions were increased yet further (though temporarily) around the one-year anniversary of the revocation of Article 370, not only because the anniversary itself was expected to inspire protests, but also because that same date was provocatively chosen as the day on which BJP Prime Minister Narendra Modi would lay the foundation stone on a Ram Temple to be built on the disputed site of the Babri Masjid ("Babar's Mosque"). ${ }^{4}$ The concurrence of these events symbolically linked them, and further fueled the perception of the BJP as a party intent on asserting Hindu dominance and control over Muslims and other religious minorities. Appraisals of the BJP's actions in Kashmir vary, though in truth there had been widespread weariness with the region's longstanding volatility, and some polls show strong public support for the party's actions there, as well as on CAA and the Supreme Court's earlier pro-Hindu decision on the contested Babri Masjid issue (India Today Web Desk 2020).

House churches raise additional issues related to freedom of religious assembly. There are no laws that regulate Indian house churches in any significant way. Still, Indians periodically become annoyed to find their neighbors hosting boisterous worship. In the absence of regulatory laws and zoning restrictions, some very small portion of those annoyed by neighboring house churches may seek extrajudicial solutions. If they have some local political clout, they may be able to convince local law enforcement officials to threaten or detain house church pastors (and/or members) on spurious charges, or to counterfactually assert that holding worship in one's house requires prior permission from local officials. If such solutions are unavailable, or ineffective, those opposed to house churches in their midst may gather others and employ mob violence or the threat of it to intimidate pastors or entire congregations into meeting elsewhere (or not at all). Such actions are often instigated by aggrieved neighbors, but they are also occasionally set in motion by non-local opponents of Christianity who are concerned less by the boisterous worship of house church Christians than by their perception that the emergence of a house church signifies the establishment of a Christian foothold in a previously unchurched area (Bauman 2020, pp. 88-89). Therefore, despite the fact that Indian law generally allows for house church worship, in the view of house church defenders, social forms of opposition such as these represent a socially-enforced restriction of religious freedom.

\subsection{Restrictions on Receipt of Foreign Donations}

India's Foreign Contribution (Regulation) Act, 2010 (FCRA) requires that NGOs receiving donations from abroad regularly and accurately report the nature and source of those donations, and further assigns to government officials the right to revoke the licenses of NGOs found violating the Act's regulations. There is nothing particularly unusual in a sovereign nation wishing to keep an eye on foreign funds received by NGOs operating within its borders, and for many years the FCRA appears to have been imposed in a largely non-partisan manner. However, the Act allows the government to deny NGOs the right to receive foreign funds if they are engaged in political activities (broadly and vaguely defined), or "any activities detrimental to the national interest." Such provisions are of course available for exploitation by government figures, who, acting unconsciously out of self-interest or more consciously for blatantly political purposes, confuse their party's interest with the nation's.

This is precisely what critics have accused the BJP of doing since it came to power in 2014. In just the first two years of its rule, the government used its FCRA powers to revoke or refuse to renew the licenses of over 20,000 NGOs (Bhattacharya 2018; Press Trust of India 2016). Most were revoked or denied for technical violations of the reporting 
procedures, as previous governments had periodically done (though not nearly on the same scale), while others were accused of engaging in activities detrimental to the national interest. Critics of the government's actions, which include UN Special Rapporteur on Freedom of Assembly and Association, Maina Kiai (2016), note with suspicion that the list of organizations targeted includes a disproportionate number of Christian and Muslim NGOs, along with a disproportionate number of the kinds of leftist universities and human rights organizations whose activities and political views generally run counter to those of the BJP.

Among organizations that have lost their licenses are prominent international NGOs like Greenpeace and Compassion International. Greenpeace, into whose activities previous governments had also inquired, has sued the government to restore its license. Meanwhile, Compassion International-accused of being a front for proselytization-shuttered its operations in India after losing the right to receive foreign funds. Indian NGOs run by Teesta Setalvad, a frequent critic of Prime Minister Modi's human rights record, similarly lost their licenses, while Act Now for Harmony and Democracy, which is run by prominent Muslim advocates for human rights, was denied a license on the basis of its "undesirable activities against public interest." ${ }^{5}$ The government has therefore targeted a full range of developmental, environmental, political, and religious organizations (including at least a few Hindu religious organizations) in its FCRA enforcement. The impression remains strong among Muslims and Christians, however, that they are being disproportionately targeted in FCRA enforcement, and that this disproportionate targeting constitutes discrimination against minority religions and an infringement upon their religious rights. Incidentally, the new restrictions have also significantly hampered COVID-19 pandemic relief efforts, with devastating and at time deadly result (Saha 2020).

\subsection{Restrictions on Proselytization}

Proselytization is restricted in India both legally and extra-legally (that is, through intimidation and violence). The section begins with a discussion of legal restrictions, before moving on to the extrajudicial acts of intimidation and violence that are often used to enforce, extend, or circumvent limits on these legal restrictions. As noted above, Article 25 of India's Constitution provides to all Indian citizens the "right to freely profess, practice, and propagate religion subject to public order, morality and health." At first glance, the Constitution would therefore seem to include within it the right to proselytize. But it does not, at least not fully, and the reason for this can be found in the history of India's Constitution and subsequent judicial rulings regarding state "Freedom of Religion" laws.

Reflecting the complexity of Gandhi's views (as described above) representatives to India's Constituent Assembly, charged with creating the young nation's constitution in the years between 1946 and 1950, debated the wisdom of ensuring the right to proselytize. Reasoning from a definition of religion similar to Gandhi's, as spiritual advance and transformation available within any religious tradition, some members of the Assembly considered proselytization disruptive and extraneous to the essential nature of religion, and therefore recommended that the new constitution forbid it (Claerhout and Roover 2019). They were eventually defeated by those who argued that evangelism was an essential component of religion and therefore of religious liberty itself. In this camp were many Christian members of the Assembly, who argued for the necessity of proselytization based on their more typically modern Christian understanding of religions as assemblages of beliefs and practices oriented around the pursuit of uniquely salvific truth (which, significantly, cannot be found in all religions). The inclusion of the right to "propagate" religion in Article 25 reflects the compromise these divergent camps eventually achieved.

What appeared to be a victory for the pro-proselytization camp was undermined two decades later, however, by the Supreme Court's ruling in the case of Rev Stanislaus vs. Madhya Pradesh (1977). The history of this ruling begins ten years earlier, when the state of Odisha passed a Freedom of Religion Act (1967) proscribing "conversion from one [r]eligion to another by the use of force or inducement or by fraudulent means." A 
year later, the state of Madhya Pradesh passed its own version of the law. ${ }^{6}$ Challenges to the constitutionality of these laws produced contradictory opinions in their respective state High Courts, which referred the matter to the Supreme Court for reconciliation. In its decision, the Court defined "propagate" in a more limited way than proposed by those in favor of proselytization, i.e., as the right to "transmit or spread one's religion by an exposition of its tenets," while explicitly stating that Article 25 did not ensure "the right to convert another person to one's own religion." ${ }^{7}$

The distinction is a fine one, and what it means in practice has been difficult to determine. On the one hand, there are no laws that clearly and explicitly forbid proselytization (again, using the term "proselytize" to denote evangelism with the intent of converting another). Even the Freedom of Religion laws (often called "anti-conversion laws" by their detractors, and now on the books in seven Indian states) forbid only conversion by "force," "fraud," "inducement," and/or "allurement". On the other hand, the ruling established that there is no constitutionally guaranteed right to proselytize. Without such a guarantee, those who engage in proselytization are vulnerable to prosecution under Freedom of Religion laws, as well as under Section 153(A) of the Indian Penal Code, which forbids the promotion of "disharmony or feelings of enmity, hatred or ill-will between different religious ... communities," or under Section 295(A) of the Indian Penal Code, a colonial-era legal holdover that threatens imprisonment to those who deliberately outrage "the religious feelings of any class," or who insult, or attempt "to insult the religion or the religious beliefs of that class" (Adcock 2016, pp. 337-51; Nair 2013, pp. 317-40).

The problem is not so much with the letter of these laws, defined narrowly. Though some of the most assertively proselytizing Christians may consider it their duty to cause offense in the context of evangelism, an aggressive position they justify with reference to biblical assertions about the "offense of the cross" (Galatians 5:11; see also, 1 Corinthians $1: 23)$, the vast majority of Christians in India, as elsewhere, would agree that evangelism should be characterized by kindness and charity, and that no Christian should seek to convert others by force, fraud, or inducement, at least so long as those terms are interpreted narrowly. The problem, as defenders of proselytization see it, lies with the tendency, particularly of lower-level Indian police officers and judges, to interpret such terms more expansively.

Is it insulting, for example, to tell another person that their religion is false? Does it promote disharmony to convert an 18 year old from her parents' religion? Is it inducement to promise a potential convert that he will be treated better in your religion than he is in his (a common tactic of Indian Christian missionaries when talking with Dalit Hindus)? Is it fraud if that turns out not to be true? Is it inducement if potential converts presume they will receive educational or economic benefits from conversion, even if such benefits are never explicitly promised or offered? Is it force to threaten eternal damnation? While most exclusivist Christians-committed as they are to the notion that salvation is available in only one religion, and therefore accordingly certain of the necessity of the freedom to evangelize and convert-would answer "no" to such questions, many non-Christians in India would answer "yes" to some or all of them. And if affirmative answers are given to such questions, then almost anybody engaged in evangelism, let alone proselytization, could be accused of transgressing the law. In fact, some Freedom of Religion laws now expressly provide affirmative answers, such as in Jharkhand's Religious Freedom Bill, 2017, which prohibits conversion by "force" and includes, within its definition of the term, "threat of divine displeasure." ${ }^{8}$ (Richards (2016) provides the most thorough overview and analysis of India's Freedom of Religion laws).

Because of the slippage in such terms, those wishing to put a stop to the growth of Christianity, or to evangelism in all forms (even within churches), are frequently able to convince sympathetic law enforcement officers to question, intimidate, detain, or even charge Christians under these laws, even if the Christians in question are operating legally according to their more narrow interpretation. A recent incident demonstrates how these legal issues connect with those surrounding house churches discussed above. According to 
International Christian Concern, in September of 2019, pastors of a house church in the state of Uttar Pradesh were roughed up by members of a mob associated with a radical Hindu group in the area. Police arrived, and arrested the pastors rather than the perpetrators of the assault. The pastors were then booked under Section 295(A) of the Indian Penal Code for allegedly outraging the religious feelings of Hindus, and were released on bail only five days later (Smith 2019). Most cases like this do not advance towards serious prosecution. Instead, detentions and requirements of repeated appearances in court are used to harass and impoverish the victims before their cases are ultimately dismissed.

In some circumstances, however, even accusations lacking the most basic forms of supportive evidence embroil their victims in serious and drawn out legal affairs. In May of 2017, for example, eight Christians transporting Christian children by train to a Bible camp near Nagpur, Madhya Pradesh, were detained by railway police. A case was registered against them for kidnapping, and they were also charged with forcible conversion under the Madhya Pradesh Freedom of Religion Act, despite the fact that the children's parents, when questioned, consistently told authorities their children had been raised Christian and were traveling with the accused with parental knowledge and permission. When the incident occurred, the children were separated from the accused, and were not even allowed to return to their parents (who came looking for them) until many hours later. Meanwhile, the accused were denied bail, and remained in jail for three months. Even reuniting the children with their parents and getting the accused out on bail required intervention from the high-powered lawyers of ADF India. Nearly three years later, in February, 2020, the eight were acquitted in court, largely because not a single witness supported the prosecution's assertions (Chari 2017b). In the meantime, however, many lost their sources of income and faced financial ruin. Two more Christians were arrested taking children to the same Bible camp only days later, and several months after that, an almost identical incident took place as another group of Christian children and their chaperones made their way to a Bible camp in Mumbai. Activists associated with strongly antiChristian, local Hindu nationalist organizations are alleged to have set all three incidents in motion (Chari 2017a).

Such stories demonstrate that Sections 153(A) and 295(A) of the Indian Penal Code, as well as state Freedom of Religion Laws, function primarily as tools of harassment and intimidation (Bauman 2008, pp. 181-213; 2010, pp. 263-90; 2013a, pp. 297-321; 2016, pp. 31-39; Bauman and Ponniah 2016, pp. 223-53; 2017, pp. 68-78). Those accused under such laws are rarely if ever convicted for their alleged crimes. Moreover, anecdotal data from lawyers involved in defending the people booked under these laws suggests that they are also far more likely to spend time in jail than those booked under other laws of similar severity, despite directives from the Supreme Court that those charged under laws with maximum jail sentences of fewer than seven years should generally not be arrested at all (unless convicted).

In addition to serving the interests of those who wish to harass and intimidate, the laws also function to prevent conversion by miring potential converts in Kafkaesque bureaucracy. Several of the state Freedom of Religion laws, for example, include provisions requiring potential converts to alert local authorities in advance of their conversion ceremonies, and/or seek permission from local authorities to convert. These authorities are tasked with determining whether the conversions are induced or coerced, and have the power to deny requests for conversion. Preliminary results from a Right to Information request filed by Indian human rights organizations, and seeking statistics on the application of such laws, indicate that at least in two states, the vast majority of conversion requests have been denied, which generally has the result of driving conversions and Christian identity underground. ${ }^{9}$

Uncertainty regarding the scope of laws regulating evangelism and conversion, along with their uneven and prejudicial application, concerns Christians who feel an obligation to evangelize but wish to do so lawfully. These same issues, however, also frustrate opponents of proselytization and conversion, who-presuming a broader interpretation of the laws- 
believe that they effectively prohibit open evangelism, proselytization, and conversion, and yet witness such things taking place all around them. Most of them express their frustration civilly. Some very small proportion of them, however, decide to take the law into their own hands and attempt to enforce a complete ban on evangelism and/or conversion through acts of intimidation and violence. Incidents of such violence have increased dramatically since the late 1990s, such that today there are around two to three hundred incidents of anti-Christian violence each year (Bauman 2013b; Bauman and Leech 2011). Research by Saiya and Manchanda (2020, pp. 587-607) suggests that states with Freedom of Religion laws in force have rates of anti-Christian violence seven times higher than that of states without them.

Relative to the size of the population, this puts the number of incidents of antiChristian violence in India well under the number of hate crimes perpetrated against both Muslims and Jews in the United States (according to FBI statistics), ${ }^{10}$ and the number of incidents of anti-Christian violence in India would be well under the number of anti-Jewish hate crimes in the US (relative, again, to the size of the population), even if these estimates of incidents of anti-Christian violence in India represented a severe undercounting.

One significant difference is that such incidents in the Indian context somewhat more regularly target Christians in the act of evangelism (or while conducting vacation Bible schools, or ordinary church services), that is, in the course of activities they consider part of their religious duty. Another primary difference is that hate crimes involving murder in the US are generally the work of disaffected young white male gunmen, whereas murders in the context of anti-Christian violence in India, which are exceedingly rare, almost exclusively take place in the context of largescale riots like those in Kandhamal, Odisha, in 2007 and 2008 (where around fifty people were killed, mostly but not exclusively Christian). Such anti-Christian riots are themselves exceedingly rare, and none in independent India have been as deadly as those in Kandhamal.

I provide this comparative data not to downplay the severity or scale of the problem in India, but rather to provide some context for assessing it. Moreover, it is important to note that these acts of intimidation and violence have significantly altered the way that evangelistic Christians behave in India (as similar attacks likely have altered the way that Muslims and Jews behave in the United States). Most significantly, many Christians who might otherwise consider evangelism a religious duty have abandoned it to avoid the risk of violence or legal harassment. For those who believe they have a right and duty to evangelize and/or proselytize, then, these forms of social violence exacerbate what they already perceive to be the legal infringement upon their religious rights as citizens of India.

The legal regulation of proselytization and conversion strikes many Western observers as a clear violation of religious liberty. The fact that it does, however, is at least partly related to the fact that such observers have been socialized, (1) within predominantly Christian cultural environments where proselytization is acknowledged, even by critics, to be a traditionally important (if not universal) aspect of religious expression, and (2) within legal frameworks that value government non-interference in religion and do not consider religious reform the government's obligation or prerogative. Indians, however, have been socialized within a different religious, legal, and political environment. Both Indian and Western courts must make determinations about what constitutes legitimate religious practice. United States courts, for example, have weighed in on whether animal sacrifice and the religious use of psychedelic drugs are necessary ritual practices. Indian courts make similar determinations according to what has come to be known as the "essential practices" doctrine described below. Comparatively speaking, however, Indian courts have more explicitly considered it their (and the government's) role to manage and reform religious practice in pursuit of what Dhavan has called "reformatory justice" (Acevedo 2014, p. 162; Dhavan 2001).

This tendency has a history that goes back to colonial times (e.g., with British intervention in practices such as sati), but is also importantly related to the fact that Indians have traditionally understood religion, interreligious relations, and religious institutions as 
social, public things which must be managed by the government for the public good, and with a view towards ensuring equitable access and interreligious harmony (Acevedo 2014; Bhargava 2005, pp. 124-25). The willingness of Indian courts to uphold the legal regulation of proselytization and conversion may be seen as an indirect expression of its "ameliorative approach" (Jacobsohn 2009, p. 17), an approach that does not merely take religion as it is but also pronounces on what religion should be, i.e., modern, rational, tolerant, inclusive, egalitarian, and not "superstitious" (Sen 2007, p. 10).

That same tendency also helps account for the victim-blaming included by the Supreme Court in its decision upholding the conviction of Dara Singh, famously charged with murdering Australian missionary Graham Staines and his two young sons in 1999: "It is undisputed that there is no justification for interfering in someone's belief ... upon [the] flawed premise that one religion is better than the other." After public backlash, the court took the extraordinary step of expunging the statement (Sinha 2011). If such statements may be seen as an indirect expression of the Indian government's inclination towards religious reform, the cases discussed below highlight controversy over its more direct expression.

\section{Majority Concerns}

Not all secularisms are alike, and while India's Constitution enshrines the nonestablishment of religion, it does not enshrine non-interference in religious affairs or command a strict separation of religion and state. Rather, acknowledging the centrality and value of religion in Indian society- the essential publicness of religion-the Indian government has adopted ideals of "celebratory neutrality" (Dhavan 2001, p. 320) and "principled distance" (Bhargava 1998, p. 7) vis-à-vis religion, positioning itself, ideally, equally close to and equally distant from all religions. As indicated above, this position has allowed for, even encouraged, Indian judicial regulation of religious affairs. Indian courts have historically engaged in both "internal regulation" of religion (i.e., determining the legitimacy of particular religious beliefs or practices by reference to authoritative utterances, doctrines, and scriptures of the religion in question) and "external regulation," e.g., through involvement in the management of religious institutions (Acevedo 2014, p. 151; 2016, p. 849).

While the Indian government and judiciary have exercised regulatory and reformatory authority over various religions, they have done so most significantly and regularly with regard to Hinduism. Moreover, whereas the Indian state's interventions in Hindu affairs have often privileged liberal and egalitarian formulations, it has been far more circumspect with regard to minority religions, leaving even their relatively regressive practices intact (perhaps out of a sense of respect for minority rights, perhaps because it is politically expedient to avoid interference in the affairs of religious minorities). This justifiably concerns many Hindus, both because it represents a greater degree of governmental interference in Hindu than minority affairs and-from the perspective of more conservative Hindus-because it constitutes a refusal to allow Hindus to cling to what some of them consider traditional beliefs and practices. Resisting government intrusion into Hindu religious affairs (or at least the expansion of it) has therefore come to be a central concern not only of the Hindu right, but also of many typical, middle-class Hindus. Two cases involving prominent Hindu Temples-Sabarimala and Padmanabhaswamy-recently reached India's Supreme Court, and are illustrative of the issues at play. The Sabarimala case turned on issues of internal regulation, whereas the Padmanabhaswamy case revolved primarily around issues of external regulation.

4.1. Government Management of Religious Institutions, the Essential Practices Doctrine, and the Sabarimala Temple Dispute

Indian governments have a long history of interfering in Hindu temple affairs to ensure equal access to all castes. The first Indian ruler to do this was Maharaja Chithira Thirunal Balarama Varma, the princely state of Travancore's young ruler. In 1936, Varma declared that no temple in Travancore could deny entry to Dalits, who were then more commonly called avarnas ("those without caste") or harijans ("children of God," Gandhi's 
neologism). At India's independence in 1947, the prohibition against denying Dalit access to public (as opposed to privately managed) temples became the law of the land, and there is broad if not universal support for it in contemporary India.

The issue of temple entry re-emerged more recently in the Sabarimala case. This time, however, the question was whether a Hindu temple could deny entry to women. For several centuries, women of child-bearing age (10-50) had been quasi-officially denied entry to the inner precincts (the sanctum sanctorum) of the temple in Sabarimala (in the state of Kerala), which is dedicated to the god, Ayyappan (or Ayyappa). Ayyappan, in Hindu mythology, is a celibate god, and therefore should not interact with women within this age range. The ban on women at the temple appears to have been unevenly imposed, but supporters of the ban on women's entry filed a Public Interest Litigation suit to have it made legally binding in 1990, after S. Chandrika, a former commissioner of the Devaswom Board (a state government office charged with administering Hindu religious affairs-see below for more) attended a rice-feeding ceremony for her granddaughter in the temple precincts. (Rice-feeding ceremonies mark a childhood transition to solid food, and are often celebrated at temples.) Chandrika was over 50, but some of her female relatives in attendance were within the prohibited age range.

Opponents of the ban on women's entry argued that it had never been uniformly applied, and that such a ban violated Articles 25 and 15 of the Indian Constitution. Article 25, discussed above, ensures religious freedom, while Article 15 prohibits discrimination on the grounds of religion, race, caste, sex, or place of birth. ${ }^{11}$ Opponents further argued that the ban transgressed upon Kerala's Hindu Places of Public Worship (Authorisation of Entry) Act, 1965, which-drafted primarily with Dalit exclusion in mind-makes provision to ensure "the entry of all classes and sections of Hindus into places of public worship" (Acevedo 2018a, pp. 561-62). ${ }^{12}$

The Kerala High Court's decision in 1991 confirmed the legality of the ban, asserted that it did not violate Articles 15, Article 25, or Kerala's Hindu Places of Worship Act, and did so primarily on the grounds that there was "no restriction between one section and another section or between one class and another class among the Hindus," because "the prohibition [was] only in respect of women of a particular age group and not women as a class." 13 Years later, in 2006, six female lawyers associated with the Indian Young Lawyers' Association petitioned India's Supreme Court to rule the ban unconstitutional. Finally, in September, 2018, in the midst of a great deal of public controversy, protests, and an unprecedented level of social media campaigning (ibid., pp. 567-68), a five-judge bench of the Supreme Court determined that the ban violated constitutional assurances of religious freedom and gender equity, as well as Kerala's Hindu Places of Worship Act.

Almost immediately, however, the court took the unusual step of referring the matter to a larger bench (of at least seven judges) for review, folding within that review other issues deemed similar, such as the entry of Muslim women into various dargahs and mosques, the entry into Parsi (Zoroastrian) fire temples of Parsi women married to nonParsis, the practice of female genital mutilation in some Indian Muslim communities, etc. Arguments have begun in that review, but a decision is still forthcoming. What is common to these various issues is the question of whether they constitute "essential practices" within their respective religions, which, under Articles 25 and 26 (which grants religious denominations freedom to manage their own affairs) of the Constitution would give them some limited protection from government interference, even if they constituted a violation of constitutional prohibitions against gender discrimination.

Understanding the dynamics of this and the Padmanabhaswamy case described below requires explanation of two interrelated issues: (1) the nature of governmental regulation of Hindu religious affairs, and (2) the "essential practices" doctrine. As indicated above, the Indian government has tended to see religious institutions, and particularly Hindu temples, as a kind of public endowment requiring government management. Government oversight of Hindu temples takes place primarily at the state level, through various boards and commissions. Among one of the most important functions of these boards and 
commissions is to redistribute excess revenue from larger and more popular temples to smaller, less wealthy ones. Each state manages temple affairs differently, and southern states, like Kerala (where both the Sabarimala and Padmanabhaswamy temples are located), tend to regulate them more thoroughly than northern states. The regulation of Hindu temples began under British rule-much to the consternation of British evangelicals-but this chapter focuses on independent Indian administrative formulations. Since both the Sabarimala and Padmanabhaswamy temples are in Kerala, and because Kerala's regulation of temple affairs is arguably more extensive than that of other states, Kerala provides a useful case study for exploring how temple regulation works in practice.

When it was created after the reorganization of Indian states in 1956, Kerala, with relatively broad public support, established five regional Devaswom (literally "Property of God," but more figuratively, "temple") Boards. These boards officially operate under a Minister of Devaswom Affairs, who is charged with overseeing the administration of around 1700 temples in the state. In reality, however, the regional Devaswom Boards have far greater influence over the affairs of temples within their geographic region. The Boards administer temples deemed "public" (which means they fall under government control, and are officially open to all), while "private" temples are owned and operated by families or trusts, and may serve limited constituencies (Acevedo 2014, p. 146). Members of the Devaswom boards are nominated by Hindus in the state government. They are powerful because of the vast sums of money they control, but they are beholden to the Kerala High Court, which oversees and conducts audits of their affairs. Temple properties theoretically belong to each temple's presiding deity, a kind of legal fiction that ensures those assets are employed to further the deity's (or, more realistically, the temple's) interests. The Devaswom Boards work with and through the trustees of individual temples, and, somewhat less directly, with the priests associated with them. Controversies, when they emerge, often concern the division of labor and authority between the Devaswom Boards, on one hand, and, on the other, the temple priests and trustees, who often claim that Article 26 of the Constitution guarantees them the right to manage their own affairs (Acevedo 2018a, p. 559).

The "essential practices" doctrine was first articulated in the Supreme Court's 1954 ruling in the Shirur Mutt case. In that case, the leader of a Hindu monastery in what is now the state of Karnataka (but was then still the state of Madras) filed suit to limit the power of Madras state government temple oversight committees (akin to Kerala's Devaswom Boards) over his management of the monastery's affairs. In court, the state defended its authority to regulate the secular activities of religious institutions, i.e., all activities that do not constitute an essential practice of religion. The court agreed, declaring that "what constitutes the essential part of a religion is primarily to be ascertained with reference to the doctrines of that religion itself" (ibid., p. 554).

The decision established precedent whereby practices deemed essential were beyond the purview of state regulation, while it at the same time legitimized government oversight of non-essential practices. The decision also stated clearly that the state should be highly deferential to the opinion of adherents, who should have "complete autonomy" (Sen 2007, p. 14) in establishing what constituted essential practice. However, subsequent decisions also quickly undermined the ideal of deference to adherents and came to rely more regularly on modern social norms than established scriptures and doctrines in the determination of what constituted an essential practice (ibid., viii, pp. 15-18). Essentially, the court's preference for "rational" religion (over "superstition"), and its reform-minded, ameliorative approach to religion took precedence over its commitment to deference, neutrality, and religious freedom. Since religious belief and doctrine are malleable, and various scriptural sources within a single tradition can be divergent and even contradictory, the essential practices doctrine has, in reality, provided judges a great deal of latitude to exercise their impulse towards reform (Acevedo 2018a, p. 555; Mehta 2010, pp. 174-93).

The Sabarimala temple dispute constitutes one such case. In its 1991 decision in favor of the ban, the courts looked to temple authorities to determine what constituted essential 
practice. The words of living priests and other authorities became particularly significant in this case because there were few ancient Sanskrit or vernacular texts to provide guidance. In the years between the 1991 decision and that in 2018, nothing much had changed in terms of the basic contours of the argument, and the centrality of the tensions between Article 15 of the constitution (prohibiting discrimination), and articles 25 and 26 (ensuring both individual and institutional religious freedom). In the 2018 decision, however, the reforming tendency of the Indian judiciary came to the fore.

In its decision, four of the five court justices signaled their willingness to define proper religion as inherently anti-discriminatory, declaring: "It is a universal truth that faith and religion do not countenance discrimination." Then, striking down the ban, the court drew upon the essential practices doctrine to argue that "In no scenario [can it be said] that exclusion of women of any age group could be regarded as an essential practice of [the] Hindu religion and on the contrary, it is an essential part of the Hindu religion to allow Hindu women to enter into a temple ..."14 While progressive and reformminded Hindus cheered the verdict, Deepa Das Acevedo has pointed out the problematic implications of such a ruling, which essentially asserts "that any religious practice deemed to be discriminatory loses its status as a religious practice by virtue of being discriminatory" (Acevedo 2018b, p. 13). It is worth nothing, by way of contrast, that Indian jurisprudence therefore runs in precisely the opposite direction of recent American decisions on similar affairs (such as in Our Lady of Guadalupe School v. Morrissey-Berru), which preserve the right of religious people to transgress, within their own religious environs, against otherwise universally applicable anti-discrimination law.

\subsection{The Padmanabhaswamy Temple Dispute}

If the Sabarimala case illuminates the contours of the essential practices doctrine in practice, the Padmanabhaswamy Temple dispute illustrates the tensions inherent in state management of institutional religious affairs. The Padmanabhaswamy Temple dispute has its roots in the close and symbiotic relationship that Indian rulers (especially but not exclusively Hindu rulers) had, before independence, traditionally cultivated with prominent temples under their jurisdiction. Such rulers would lavish endowments upon temples and pay respect to their presiding deities, sometimes even symbolically declaring that they ruled only as regents on behalf of the deities. In return, temple clergy and those under their control would confirm the legitimacy and/or divine nature of the ruler's reign. Such was the nature of the relationship between the ruling family of Travancore (the princely state mentioned in the earlier discussion of temple entry) and the Padmanabhaswamy Temple.

When the princely state of Travancore acceded to India in 1949, the royal family was granted authority within a trust vested with the administration of the temple. The trust was directed by Maharajah Chithira Thirunal Balarama Varma-the very same one who had opened temples in his realm to Dalits—until his death in 1991, when the directorship was taken up by his younger brother, Uthradam Thirunal Marthanda Varma. Treated as a private temple, it was therefore not among the temples controlled by Kerala's Devaswom boards. By all accounts, this arrangement functioned relatively well for many years.

Controversy erupted, however, when, in 2007, Marthanda Varma signaled his desire, as trustee of the Padmanabhaswamy Temple, to open its vaults in order to catalog and photograph its great wealth (received, in no small part, from his royal ancestors). Officially all parties in the dispute, including the younger Varma and other descendants of Travancore's erstwhile rulers, accepted the notion that any objects of value held by the temple were owned by its presiding deity. But Varma muddied the waters, when, in an interview defending his desire to catalog the temple's riches, he opined that the vaults held "the wealth that [his] family accumulated over several generations" (Emphasis added. Acevedo 2016, pp. 850-51, 855). The statement raised suspicions about his intentions, and, predictably, reports emerged alleging the royals had periodically made off with artifacts among the temple's riches. But the incident also provoked sensationalized speculation about the value of the temple's treasure, which included, inter alia, divine images and 
elegant jewelry wrought in gold, silver, and precious stones, and coins from across the ancient and modern world. As part of the ensuing legal battles, the vaults were opened and cataloged, with some estimates of the treasure's value topping US $\$ 13$ billion.

Varma's actions provoked several temple devotees to file writ petitions and public interest litigation suits. These various suits, calling for greater government oversight of the temple's affairs, were clubbed together along with a suit filed by T.P. Sundara Rajan's as T.P. Sundara Rajan vs. The State of Kerala. The royal family opposed these calls for greater government oversight in their own suit, Uthradam Thirunal vs. Union of India. Since the covenant established between the state of Travancore and the government of India had vested temple authority in the hereditary rulers of Travancore, a key element in the debate was whether Marthanda Varma, who would have inherited the throne upon his brother's death if Travancore had not acceded to India, could properly be considered a ruler simply because he was the heir of the royal family (ibid., pp. 852-53).

The Kerala High Court considered the suits together. In its 2011 decision, the Court determined that Marthanda Varma could not be considered a ruler in any proper sense, and that he and his family therefore did not retain trusteeship of the temple. Accordingly, the court ordered the Kerala state government to establish a trust to administer the temple, administer an inventory of the vaults, and provide police protection for the temple's wealth (ibid., p. 853).

According to Acevedo, the decision, and public debate about it, focused on three interrelated issues: "who owned the treasure, who should administer the treasure, and in whose interests should the treasure be administered?" (ibid., p. 855). Various social, political, and religious leaders weighed in on these issues. All parties essentially agreed that the temple's wealth belonged to its deity, but what did that mean in practice? Should it be used solely for temple maintenance? Or should it be used for some broader public good? What would it mean to serve the public good? Should the artifacts be displayed in a museum (which would also benefit the temple through entrance fees)? Should they be sold and used to fund a Hindu university? And who constituted the public? All citizens of Kerala, or Hindus only?

The High Court's decision established the duty of the government to administer public religious endowments for the purpose of ensuring that they were used in the best interests of devotees and in service of a more general public good. The decision also re-affirmed the notion that Hindu religious institutions were in need of government oversight (ibid., pp. 863). That view, established already in colonial times, rankled many Hindus, particularly those not in agreement with the government's reformatory impulse or the fact that it has been more forcefully applied to Hinduism than India's minority religions.

It was for this reason that many cheered the Supreme Court of India, when, in July, 2020, it reversed the decision of the Kerala High Court. After a long and controversial study of the temple's wealth and management, the Supreme Court re-established the Travancore royal family as the proper trustee of the temple. In fact, though, very little changed. While Travancore royal family members retain their trusteeship and rights to conduct significant rituals at the temple, they still must do so in consultation with two separate external committees that include government officials. The first is a government administrative committee headed by a district judge of Thiruvananthapuram (the city in which the temple is located). This committee also includes the temple's chief priest and three additional members, one each nominated, respectively, by the Travancore royal family, the Kerala government, and the national culture ministry. The second is an advisory committee chaired by a retired Kerala High Court judge and also including an "eminent person" nominated by the royal family and a chartered accountant nominated by the chair. The accountant is responsible for the annual auditing of the temple's finances (Choudhary 2020). Ultimately, the decision does nothing to undermine the view that the government has a right and an obligation to manage temple affairs, which at least some Hindus do welcome, since there is some concern that temples, left to themselves, will be inefficiently or corruptly managed. 
Still, many Hindus, particularly those of a more traditionalist bent, celebrated the decision as a victory over government intrusion into Hindu religious affairs. Support for the decision was particularly strong among those embracing the ideology of Hindutva, many of whom had portrayed the Kerala High Court's decision as an example of the state victimizing Hindus, and had fought in other contexts to rescue temples from what they perceive to be government intrusion, including recently at the famous temples of Jagannath and Nataraja (Choudhary 2019; Moodie 2018, chp. 2; Sen 2007, pp. 25-26). But as Pratap Bhanu Mehta has argued, since all possible managers of the temple and members of government administrative committees are and have been Hindu, and since the state that intervened in temple affairs did so with authority given to it by a Hindu-majority population, the question was never about non-Hindu interference in the affairs of the temple. It was merely about which Hindus would control it, and for what purposes (Mehta 2020).

\section{Conclusions}

\section{Litigating the Limits of Religion, and Prospects for Common Cause}

In the discussion above, the heuristic division of "minority" and "majority" concerns represents something of an oversimplification. On most of the issues discussed in this article, it is easy to find diverse opinions within both majority and minority communities. For example, while all Muslims may have reason for concern about the loss of Muslim religious freedom in Kashmir, many less evangelistic Christians are not terribly concerned about the restriction of proselytization and conversion (because they themselves have concerns about the aggressive evangelism of their coreligionists). Similarly, more progressive Hindus tend to be less concerned than more traditionalist Hindus about the judiciary's "ameliorative approach" to reforming religion, or about government management of religious affairs, which more progressive Hindus may consider necessary to ensure that religious institutions truly and efficiently serve the public good.

Furthermore, majority and minority opinion converges on a number of significant matters. For example, while the government has intervened most assertively in the management of Hindu institutional affairs, it has also interceded periodically in the management of minority religious institutions (most famously, perhaps, in the Haji Ali Dargah case, in which Indian courts forbade the exclusion of women from the inner sanctum of a Muslim mosque and shrine containing the tomb of a famous Sufi saint). Such management is therefore not exclusively a majority concern. Indeed, Hindus angered about government management of temples, Muslims outraged about the curtailing of Kashmiri's religious freedom, and Christians incensed about the legal and extra-legal circumscription of evangelism and conversion are all essentially concerned about state interference in religious affairs. There is therefore potential here for mutual understanding and the expression of common concern.

Another fascinatingly complex and cross-cutting issue is India's complex system of personal laws. While Article 44 of the Directive Principles of State Policy in India's Constitution requires the state to develop a Uniform Civil Code (UCC), in reality, successive Indian governments have failed to undo the colonial-era system of religion-specific personal laws governing matters of marriage, divorce, inheritance, and the guardianship and maintenance (after divorce) of women. Because of this, discrete personal laws for Parsis (Indian Zoroastrians), Muslims, Jews, Christians, and Hindus remain in effect, with Hindu law constituting, by default, the law for all those not governed by Parsi, Muslim, Jewish, or Christian law. On the one hand, the continued existence of these laws preserves a certain degree of freedom and autonomy for religious minorities. On the other hand-though it is complicated and not always the case (Menon 2014, p. 482) — the Hindu personal law code is perceived by many to ensure the rights and fair treatment of women better than the personal laws of minority religions. There is also regular controversy, within minority communities, about which individuals or institutions have the right and authority to represent them in discussions about personal law (Shankar 2018, p. 131). 
The UCC controversy has therefore at times pitted advocates of minority religious freedom against advocates for gender justice within their own traditions, and particularly so since the 1990s, when leaders on the Hindu right began framing their support for the UCC on precisely these terms. For a time, this made strange bedfellows of the Hindu right and secular, Hindu, and non-Hindu Indian feminists, whose politics otherwise evinced a distinctly leftward inclination. More recently, however, feminists have become muted in their support for the UCC, in part because of their apprehension that what really motivates the Hindu right's support for the UCC is not a concern for women so much as a desire to further homogenize the nation in accordance with prevailing Hindu social norms, but also in part because of a recognition that certain aspects of the minority religious personal laws are more progressive than their equivalents in Hindu law (Menon 2014, pp. 481-82). While cases like this therefore have the potential to divide religious communities within themselves, they also generate the possibility of interfaith alliances.

There remains, however, a significant obstacle to the development of a broader Indian unity on matters of religious freedom. While the cases described in this article may appear to involve more technical questions about the appropriate level of state involvement in religious affairs, at a more fundamental level, the question being litigated is the definition of religion itself. The Indian Constitution's subordination of religious liberty to "public order [and] morality," and the judiciary's reforming, ameliorative approach to religion, signals the state's willingness, even obligation, to adjudicate not only what religion is, but also what it should be. The courts have done this in several significant ways.

First, since the 1990s, Indian justices have increasingly made a distinction between religion and dharma, arguing that it is the latter, not the former, that is protected by the Constitution. As Justice B.L. Hansaria put it, "religion ... is comprised of rituals, customs, and dogmas surviving on the basis of fear and blind faith; whereas dharma encapsulates those great laws and disciplines that uphold, sustain, and ultimately lead humanity to the sublime heights of worldly and spiritual glory (Sen 2007, p. 27; 2010). This distinction is a typically Indian one, and echoes the tendency of many Hindus to speak of their tradition not as "Hinduism" or as "religion" but as sanatana dharma (eternal dharma), something prior to, different from, and superior to religion as it is manifest in particular dogmas and rituals.

Second, because dharma, by this definition, is beyond and prior/superior to religion, the distinctions of various religions are ultimately meaningless when judged by the standard of efficacy. All religions are flawed; all religions also have potential to "lead humanity to the sublime heights of worldly and spiritual glory" (to use Justice Hansaria's construction). If this is true, then proselytization is utterly misguided and disrespectful. If proselytization is misguided and disrespectful (and, moreover, likely to threaten "public order"), it may not constitute an "essential practice," and the state can ensure religious liberty without ensuring the right to proselytize. In turn, this helps explain the court's (ultimately self-censored) opinion in the Dara Singh case, discussed above, that "there is no justification for interfering in someone's belief ... upon [the] flawed premise that one religion is better than the other." While some Indian Muslims and Christians may be able to reconcile themselves to such a view, the assertion that only dharma (not religion) is constitutionally protected, and that dharma is necessarily tolerant in a way that prohibits proselytization, tends to divide adherents of the Indic religions from what opponents label "foreign" religions like Christianity and Islam.

The force of the judicial shift described in the previous paragraphs has been compounded by decisions in several 1996 cases collectively referred to as the Hindutva cases. These cases considered whether it was illegal for politicians to use the language of Hindutva under section 123(3) of the Representation of the People Act, 1951, which prohibits election candidates from appealing to voters on the basis of religion. In these rulings, the Supreme Court determined that appeals based on the language of Hindutva were not illegal because both Hinduism and Hindutva referred not to religion in a typical sense of the term, but rather to a "way of life," a way of life that was, for all intents and purposes, equivalent to In- 
dianness. Furthermore, the judges involved in these cases framed this Hindutva/Indianness as inherently all-encompassing and inclusive (of all religions), such that by definition it could not be partisan. What is particularly perplexing about these decisions is that just a few years earlier, in Bommai v. Union of India (1994), the courts had taken a significantly more negative view of the ideology of Hindutva (Shankar 2018, p. 130).

The rulings' portrayal of Hinduism and Indian culture drew inspiration from the kind of inclusive, tolerant religious perspective of India's secular forefathers (e.g., Nehru and Radhakrishnan). The decisions were also cheered by the political proponents of Hindutva and taken as a vindication of their view that the ideology of Hindutva was not in any way exclusionary. What India's early secularists and proponents of Hindutva have in commondespite their significant differences-is the desire to homogenize Hinduism (and India's religious landscape more generally) along the lines of this inclusive vision that understands all religions as spiritually efficacious (or potentially so) and therefore acceptable/desirable (Sen 2019, pp. 29-30).

The unresolved question in this vision is of course what to do with the religions (especially exclusivistic forms of Christianity and Islam) that reject its most fundamental premise. Whereas India's early secularist apologists (like Nehru and Radhakrishnan) adopted a more compromising posture with regard to such religions, today's proponents of Hindutva are more willing to use state policy to exclude and marginalize them. Such religions should be marginalized and excluded, from this perspective, for the sake of preserving the fundamentally inclusive nature of Hindutva/Indian culture (ibid.). So long as this tension remains within the formulation of Indian secularism and judicial conceptions of (desirable) religion, unity on matters of religious freedom will remain elusive.

Defining constitutionally protected religion as dharma, and dharma as inherently tolerant and non-exclusive, tends to pit adherents of Indic religions against adherents of exclusionary forms of Christianity and Islam (though always inconsistently and unevenly so). Conversely, a third way in which the judiciary has tended to define religion-as inherently "rational" and "modern" — tends to pit those who engage in popular religious practices against their more philosophically inclined coreligionists. Remember Justice Hansaria's assertion, above, that religion survives "on the basis of fear and blind faith." Dharma, by contrast (in this way of thinking), is something more lofty, more moral, more rational. The presumption that only rational religion is protected by the Indian Constitution leads the courts to declare popular and "superstitious" practices non-essential, and therefore available for government regulation. "American courts have usually tried to avoid sitting in judgement on 'religious error' or 'religious truth,'" Ronojoy Sen writes, whereas the "Indian Supreme Court has travelled an opposite path, seeking to cleanse Hinduism of what it reads as superstition and providing it with a modernist and rationalist definition of religious error and religious truth" (Sen 2010, p. 86; Shankar 2018). A relevant case is currently before the Supreme Court, and has to do with a Kerala state law that prohibits the religious sacrifice of animals. Opponents of the law have appealed to the Supreme Court to have it struck down. The opponents, Shakti worshippers, believe animal sacrifice is necessary (i.e., an "essential practice") to ensure the power and pleasure of their Goddess. ${ }^{15}$

In his monumental Genealogies of Religion, Talal Asad made two arguments that at first blush appear contradictory, so much so that they have periodically led to confusion and divergent interpretations of his work. The first is that there can be no universal, transhistorically and transculturally valid definition of religion, since all definitions of religion-and even the notion that religion can be clearly distinguished from things like ethnicity and politics and defined as a transhistorical and transcultural essence (Asad 1993, p. 28) - are parochial, the "historical product of discursive processes" (ibid., p. 29) guided according to the interests of those with the power to do so. The second argument is that one particular parochial definition, a "modern, privatized Christian one" that "emphasizes the priority of belief as a state of mind" (ibid.), which is taken to self-evidently recommend or even demand the confinement of religion through secular political formations like those 
prevailing in the modern West, is now regnant and quasi-universal in modern society, having been progressively more thoroughly imposed through processes of colonization, neo-colonialization, and globalization, which have served and continue to serve the interests of Western elites. These arguments are contradictory only if one fails to recognize that the first is a theoretical one drawn from historical analysis, while the second is a statement about the distinctive dynamics of our particular historical moment.

Though he does not doubt the progressive diffusion and global influence of modern Western conceptions of religion and their attendant political formations, Robert W. Hefner, in his article for this special issue, criticizes Asad for overstating their ubiquity and hegemony. The criticism is justified, and in fact we can properly understand the peculiar dynamics of institutional religious freedom in India only if we allow Asad's first argument to chasten the second. It is undeniable that modern Western conceptions of religion (and the politics they recommend) have a certain cachet among both liberal, Western-leaning secularists and religious minorities in India, particularly Christians (Bauman 2020). It is equally true, however, that these conceptions are not universal in large part because they do not align with the historical or contemporary self-understandings of those Westerners tend to call "Hindu" (but who, for related reasons articulated above, often prefer alternative terms for both "religion" and "Hinduism"). My argument here is not necessarily that scholars cannot construct a transhistorically or transculturally valid definition of religion-though, full disclosure, I remain with Asad on this point, in large part because of my engagement with Hindus and Hinduism - but rather that at the level of popular discourse, that is, at the level of what Taylor (2003) calls the "social imaginary," there exist in India multiple and competing conceptions of religion that recommend, give rise to, and create tension among divergent and sometimes contradictory political arrangements.

Similar tensions exist at the core of all secular legal frameworks. Far from being neutral in matters of religion, all secularisms must, to preserve themselves, determine the nature and limits of acceptable (and therefore legal) religion. At a minimum, for example, most secular governments prohibit the development and imposition of theocratic forms of religion. The Indian case is therefore different not so much in substance as in degree and style, i.e., in the distinctive ways in which the inherent tensions of Indian secular governance are manifest. As the cases described above indicate, one distinctive element of the Indian situation is the judiciary's willingness and sense of obligation to bend the trajectory of religious reform in the direction of what is considered modern, rational, tolerant, and inclusive. In this way, the Indian courts are more explicitly engaged (in comparison with some of their counterparts in other secular contexts) in defining religion. It is clear that such a project is inherently fraught, however, if we accept Asad's claim that all definitions of religion are tinctured by their peculiar historical and cultural circumstances, and if we keep in mind the fact that contemporary India is situated, more than many other nations, at the crossroads of divergent global religious visions. It may be that the Indian judiciary's more activist approach to such matters is precisely what is necessary to forge greater consensus around a distinctively Indian conception of religion that will at some point decisively displace or neutralize the modern, Western, privatized one Asad considers globally ascendant. That Western conception remains influential in India, however-though not influential enough to entirely displace other more local conceptions-and it is therefore just as likely that consensus and solidarity on matters of institutional religious freedom will continue to be possible only episodically, as particular cases and issues generate unique and ephemeral interreligious constellations of solidarity and alliance.

Funding: Work on this paper was made possible by a grant from the John Templeton Foundation to the Religious Freedom Institute for a three-year research project on the Freedom of Religious Institutions in Society.

Conflicts of Interest: The authors declare no conflict of interest. The funders had no role in the design of the study; in the collection, analyses, or interpretation of data; in the writing of the manuscript, or in the decision to publish the results. 


\section{Notes}

1 In the article, I use the term "proselytization" to denote evangelism with the explicit intent to convert another person to one's faith.

2 The other nine were Iraq, Syria, Israel, Nigeria, Libya, Egypt, Pakistan, the Central African Republic, and Sri Lanka.

3 Along with Burma, China, Eritrea, Iran, Nigeria, North Korea, Pakistan, Russia, Saudi Arabia, Syria, Tajikistan, Turkmenistan, and Vietnam.

4 The mosque had been torn down by Hindu nationalists in 1992 because of their claims (which the Supreme Court recently more or less accepted), that it had been built under the direction of the Muslim Mughal emperor, Babar, on the ruins of a temple marking the birthplace of the Hindu God, Ram.

5 The decision is available at: https:/ / fcraonline.nic.in/Home/PDF_Doc/fc_revision_notice_15122016.pdf (accessed on 11 August 2020).

6 The Odisha Act is available at: https://cjp.org.in/wp-content/uploads/2017/12/ORISSA-FREEDOM-OF-RELIGION-ACT-1967 .pdf (accessed on 11 August 2020). The Madhya Pradesh Act is available at: http://www.bareactslive.com/MP/MP218.HTM (accessed on 11 August 2020).

7 The full ruling can be accessed at: https://indiankanoon.org/doc/1308071/?_cf_chl_jschl_tk_=07d8454a56f2dde4ffec98fa8f9 4de686aec9272-1597167222-0-AWXw1obDpn4L1frderuypFyBcj8TbtPHeZqUx0X6POdKm19eSwW6MABhc1qxiG63hCC-JKjJNp3 OGIiJMy6gydUYDtfZ2s9u7c1fPzTEW6qbGJXMm2P7xXpJ040GWawi_0HcR5xh-AQ7Y_ck_kpvi-UAE-Wq0qIsmrBGiWr9v1cnX8 WRLXhN63zD3ZMaLOS7FT0P0oCdklsb4kxVfNMP_LhbCEnvKeP4f_pj4pD8AYhTyA0WLnSW9vQOWDxQwio_DnB9W0-RMX HLsr_p7AzRLUaNpMrgQVcz-kP0JJzoymskSsZg6q8WxgQlB9jN3-o34igysxg10Vp5OlnIQDz6SdFyDEdt1oXTQ4tSrex4FFoQ (accessed on 11 August 2020).

8 The law can be accessed at: https://www.indiacode.nic.in/bitstream/123456789/4743/1/657_2_2017.pdf (accessed on 11 August 2020).

9 I have not named the lawyers with whom I have spoken on these matters for the purposes of preserving their anonymity.

10 FBI statistics are available at: https://www.fbi.gov/investigate/civil-rights/hate-crimes (accessed on 11 August 2020).

11 The full text is available at: https: / /indiankanoon.org/doc/609295/?_cf_chl_jschl_tk_=76678c268dfd09e43a8c7ac7ec287d69625 21bfe-1597415231-0-Af7vc-iTIFKDGoTKJ1qe1iw1B0WZN5uub0ACbcfgBXkKNdjxBmE4FZm-um2Iooq-DmZgRi4S6yoq11bg9wh K3Ost7sfZ2bFPri9O3zpRZ2zaa5qKYJHcOyMG8_rgUO6i_ZG9E4meSn-bueRWnNe7ycIw4_NjAWZDRBDmUG8MVXtMUggcmENefO5nhIB_TeywpEftPyuIo9XZqOzORbiVwBHw_2R7OA1Co4LGGv0xDN334QplzQ6xaIqwa5foqOD9a4ONboLTZAB6S0OXHe7 WVyGqeaynjYhL4StQvs9ADLCKtqOLSFmlutj1XL0ICYdmWc20_surh0xMmlcwvi6r7P8_ny4t9Gtw7eB1AwHBA0N (accessed on 14 August 2020).

12 The Act is available at: http:/ / www.bareactslive.com/KER/ker080.htm (accessed on 14 August 2020).

13 The case is known as Mahendran vs. TDB. The full ruling is available at: https://indiankanoon.org/docfragment/1915943/ ?formInput=PUBLIC\%20WORSHIP (accessed on 14 August 2020).

14 Significant excerpts of the decision in Indian Young Lawyers Association vs. The State of Kerala (2018) can be found at: https:// indiankanoon.org/docfragment/163639357/?big=3\&formInput=thanthri\%20\%20doctypes:\%20supremecourt\&_cf_chl_jschl_tk_ _=4d59f95c6b1d46117e1d7e81d73bb7f34f9fbfb4-1597432188-0-ARnCVD-xaogfkGq-k716M8vZ0YfpkYZS6LgXioqiRapWXV-RiAFT nZpCEjJcoFd-WMqwSckPxHMt0p-3GnXOf3NU5MY-zBS09d6eAwy9LutBgI-t4-sAdyegzppuX_EPo0h4hNwj61pnm6gbVJtPN8 _6QKqzfsxfPfcLxNqiqv1bvfJwHxKQ0GDtsymi4glXITEqtbLfVzCru6pPh5mai-jJhpiOMW14H8wmT2WR7aucbE9XpqrRCe73mtLc xr56N_cuLT27cwy5EVvNrr3I1iaCwO8PZFM75B_TfR2D5MXM2CK-663zzytdTByeKLqe-N-SqQLdDAAZJ5cRMHvbiwjmet8MF6 FORsNDr-m71rXEvxfK8PkN2ha895rUS1tE8zCGYi2WA4rt9Fkg4xu1rTYBI3OJyFsLDdQuRNakSWmxcQBrx59N7JtXEbKfHUeU kQ (accessed on 14 August 2020).

15 The Kerala law in question is the Kerala Animals and Bird Sacrifices Prohibition Act of 1968. See (Legal Correspondent 2020).

\section{References}

Acevedo, Deepa Das. 2014. Secularism in the Indian Context. Law \& Social Inquiry 38: 138-67.

Acevedo, Deepa Das. 2016. Divine Sovereignty, Indian Property Law, and the Dispute over the Padmanabhaswamy Temple. Modern Asian Studies 50: 841-65. [CrossRef]

Acevedo, Deepa Das. 2018a. Gods' Homes, Men's Courts, Women's Rights. International Journal of Constitutional Law 16: 552-73. [CrossRef]

Acevedo, Deepa Das. 2018b. Pause for Thought: Supreme Court's Verdict on Sabarimala. Economic E Political Weekly 53 : 12-15.

Adcock, Cassie S. 2010. Sacred Cows and Secular History: Cow Protection Debates in Colonial North India. Comparative Studies of South Asia, Africa and the Middle East 30: 297-311. [CrossRef]

Adcock, Cassie S. 2016. Violence, Passion, and the Law: A Brief History of Section 295a and Its Antecedents. Journal of the American Academy of Religion 84: 337-51. [CrossRef]

Adcock, Cassie S. 2018. Cow Protection and Minority Rights in India: Reassessing Religious Freedom. Asian Affairs 19: 340-54. [CrossRef]

Asad, Talal. 1993. Genealogies of Religion: Discipline and Reasons of Power in Christianity and Islam. Baltimore: Johns Hopkins University Press.

Bauman, Chad M. 2008. Postcolonial Anxiety and Anti-Conversion Sentiment in the Report of the Christian Missionary Activities Enquiry Committee. International Journal of Hindu Studies 12: 181-213. [CrossRef] 
Bauman, Chad M. 2010. Identity, Conversion and Violence: Dalits, Adivasis and the 2007-2008 Riots in Orissa. In Margins of Faith: Dalit and Tribal Christianity in India. Edited by Rowena Robinson and Joseph Marianus Kujur. Washington, DC: Sage, pp. $263-90$.

Bauman, Chad M. 2013a. Does the Divine Physician Have an Unfair Advantage? The Politics of Conversion in Twentieth-Century India. In Asia in the Making of Christianity: Agency, Conversion, and Indigeneity. Edited by Jonathan Seitz and Richard Fox Young. Leiden: Brill, pp. 297-321.

Bauman, Chad M. 2013b. Hindu-Christian Conflict in India: Globalization, Conversion, and the Coterminal Castes and Tribes. Journal of Asian Studies 72: 633-53. [CrossRef]

Bauman, Chad M. 2016. Faith and Foreign Affairs in India: Legal Ambiguity, Selective Xenophobia, and anti-Minority Violence. The Review of Faith \& International Affairs 14: 31-39. [CrossRef]

Bauman, Chad M. 2020. Anti-Christian Violence in India: History, Theory, Interpretation. Ithaca: Cornell University Press.

Bauman, Chad, and Tamara Leech. 2011. Political Competition, Relative Deprivation, and Perceived Threat: A Research Note on anti-Christian Violence in India. Ethnic and Racial Studies 35: 2195-216. [CrossRef]

Bauman, Chad, and James Ponniah. 2016. Christianity and Freedom in India: Colonialism, Communalism, Caste, and Violence. In Christianity and Freedom, Volume 2: Contemporary Perspectives. Edited by Allen D. Hertzke and Timothy Shah. Cambridge: Cambridge University Press, pp. 222-53.

Bauman, Chad, and James Ponniah. 2017. Christian Responses to Discrimination and Violence in India and Sri Lanka: Avoidance, Advocacy, and Interfaith Engagement. The Review of Faith \& International Affairs 15: 68-78.

Bhargava, Rajeev. 1998. Introduction. In Secularism and Its Critics. Edited by Rajeev Bhargava. New Delhi: Oxford University Press, pp. 1-30.

Bhargava, Rajeev. 2005. India's Secular Constitution. In India's Living Constitution: Ideas, Practices, Controversies. Edited by Zoya Hasan, E. Sridharan and R. Sudarshan. London: Anthem Press, pp. 105-33.

Bhattacharya, Deya. 2018. FCRA Licenses of 20,000 NGOs Cancelled: Act Being Used as a Weapon to Silence Organisations. Firstpost. October 26. Available online: https:/ / www.firstpost.com/india/fcra-licences-of-20000-ngos-cancelled-act-being-usedas-weapon-to-silence-organisations-3181560.html (accessed on 9 March 2020).

Chari, Mridula. 2017a. Forced Detention: How Hindutva Groups in MP Targeted Children Heading to Mumbai for Bible Study. Scroll.In. November 9. Available online: https://scroll.in/article/857187/forced-separation-how-hindutva-groups-in-mptargetted-children-heading-to-mumbai-for-bible-study (accessed on 11 August 2020).

Chari, Mridula. 2017b. 'They Called Us Traitors': In MP, a Teenager is among 10 People Charged with Forced Conversions. Scroll.In. November 10. Available online: https://scroll.in/article/857306/they-called-us-traitors-in-mp-a-teenager-is-among-ten-peoplecharged-with-forced-conversions (accessed on 11 August 2020).

Choudhary, Amit Anand. 2019. Temples Should be Managed by Devotees, not Government: SC. Times of India. April 8. Available online: https:/ / timesofindia.indiatimes.com/india/temples-should-be-managed-by-devotees-not-government-sc/articleshow / 68781876.cms (accessed on 17 August 2020).

Choudhary, Amit Anand. 2020. Travancore Royals Get Mangerial Rights over Padmanabha Temple. Times of India. July 14. Available online: https:/ / timesofindia.indiatimes.com/india/travancore-royals-get-managerial-right-over-padmanabha-temple/ articleshow /76948913.cms (accessed on 17 August 2020).

Claerhout, Sarah. 2010. “Losing My Religion": Conversion, Secularism and Religious Freedom in India. Ph.D. dissertation, Ghent University, Ghent, Belgium.

Claerhout, Sarah. 2014. Gandhi, Conversion and the Equality of Religions: More Experiments with Truth. Numen 61: 53-82. [CrossRef]

Claerhout, Sarah, and Jakob de Roover. 2019. Religious Freedom and the Limits of Propagation: Conversion in the Constituent Assembly of India. Religions 10: 157. [CrossRef]

Dhavan, Rajeev. 2001. The Road to Xanadu: India's Quest for Secularism. In Religion and Personal Law in Secular India: A Call to Judgment. Edited by Gerald J. Larson. Bloomington: Indiana University Press, pp. 301-22.

Embree, Ainslie T. 1990. Utopias in Conflict. Berkeley: University of California Press.

Engineer, Irfan, Dabhade Neha, and Suraj Nair. 2020. Mob Lynching in 2019-Continuing Expression of Hegemony. Secular Perspective. February 16-19. Available online: https:/ / csss-isla.com/secular-perspective/mob-lynching-in-2019-continuing-expression-ofhegemony / (accessed on 10 August 2020).

India Today Web Desk. 2020. Revocation of Article 370 Single Biggest Achievement of Modi Govt: Mood of the Nation. India Today. August 7. Available online: https:/ / www.indiatoday.in/mood-of-the-nation/story/revocation-of-article-370-single-biggestachievement-of-modi-govt-mood-of-the-nation-1708959-2020-08-07 (accessed on 10 August 2020).

Jacobsohn, Gary Jeffrey. 2009. The Wheel of Law: India's Secularism in Comparative Constitutional Context. Princeton: Princeton University Press.

Kiai, Maina. 2016. Analysis on International Law, Standards and Principles Applicable to the Foreign Contributions Regulation Act 2010 and Foreign Contributions Regulation Rules 2011. Geneva: United Nations Human Rights Office of the High Commissioner.

Legal Correspondent. 2020. Supreme Court to Examine Kerala Act on Animal, Bird Sacrifices. The Hindu. July 16. Available online: https: //www.thehindu.com/news/national/kerala/sc-to-examine-kerala-act-on-animal-bird-sacrifices/article32103227.ece (accessed on 18 August 2020).

Mehta, Pratap Bhanu. 2010. India: The Politics of Religious Reform and Conflict. In Religion, the Enlightenment, and the New Global Order. Edited by John M. Owen and J. Judd Owen. New York: Columbia University Press, pp. 174-93. 
Mehta, Pratap Bhanu. 2019a. Modi Pushes India into Revolt: A New Law Upends What it Means to be Indian. Foreign Affairs. December 20. Available online: https://www.foreignaffairs.com/articles/india/2019-12-20/modi-pushes-india-revolt (accessed on 10 March 2020).

Mehta, Pratap Bhanu. 2019b. Winning Kashmir and Losing India: How Modi is Gutting Indian Democracy. Foreign Affairs. September 20. Available online: https://www.foreignaffairs.com/articles/asia/2019-09-20/winning-kashmir-and-losing-india (accessed on 10 March 2020).

Mehta, Pratap Bhanu. 2020. PB Mehta Writes: Padmanabhaswamy Case Turns on Specific Facts, but There Are Wider Political Ramifications. The Indian Express. July 21. Available online: https://indianexpress.com/article/opinion/columns/padmanabhaswamycase-kerala-pb-mehta-6515406/\#: \{\}:text=The\%20Supreme\%20Court\%20held\%20that,finding\%20turned\%20on \%20two \%20 claims.\&text=The $\% 20$ findings $\% 20 \mathrm{in} \% 20$ the $\% 20$ Padmanabhaswamy,facts $\% 20$ specific $\% 20$ to $\% 20$ the $\% 20$ case (accessed on 17 August 2020).

Menon, Nivedita. 2014. A Uniform Civil Code in India: The State of the Debate in 2014. Feminist Studies 40: 480-86.

Moodie, Deonnie. 2018. The Making of a Modern Temple and a Hindu City. New York: Oxford University Press.

Nair, Neeti. 2013. Beyond the "Communal" 1920s: The Problem of Intention, Legislative Pragmatism, and the Making of Section 295a of the Indian Penal Code. Indian Economic and Social History Review 50: 317-40. [CrossRef]

Pew Research Center. 2020. In 2018, Government Restrictions on Religion Reach Highest Level Globally in More Than a Decade. Available online: https://www.pewforum.org/wp-content/uploads/sites/7/2020/11/PF_11.10.20_religious.restrictions.full_ .report.pdf (accessed on 24 May 2021).

Press Trust of India. 2016. FCRA Licenses of 20,000 NGOs Cancelled. Times of India. December 27. Available online: https: / timesofindia. indiatimes.com/india/fcra-licences-of-20000-ngos-cancelled/articleshow/56203438.cms (accessed on 11 August 2020).

Rao, Smitha. 2011. Saffronisation of the Holy Cow: Unearthing Silent Communalism. Economic and Political Weekly $46: 80-87$.

Richards, Ian Douglas. 2016. Poles Apart: The Debate on Religious Conversion in Post-Independence India. Ph.D. dissertation, University of Toronto, Toronto, ON, Canada.

Saha, Pradip K. 2020. Why NGOs Want to Help but Can't. The Morning Context. May 28. Available online: https://themorningcontext. com/chaos/why-ngos-want-to-help-but-cant (accessed on 29 May 2021).

Saiya, Nilay, and Stuti Manchanda. 2020. Anti-Conversion Laws and Violent Christian Persecution in the States of India: A Quantitative Analysis. Ethnicities 20: 587-607. [CrossRef]

Scroll Staff. 2019. This Is What Kashmir Looks Like after 61 Days of 'Normalcy'. Scroll.In. October 4. Available online: https: //scroll.in/article/939269/this-is-what-kashmir-looks-like-after-61-days-of-normalcy (accessed on 10 August 2020).

Sen, Ronojoy. 2007. Legalizing Religion: The Indian Supreme Court and Secularism. Volume 30: Policy Studies. Washington, DC: The East-West Center.

Sen, Ronojoy. 2010. The Indian Supreme Court and the Quest for a "Rational" Hinduism. South Asian History and Culture 1: 86-104. [CrossRef]

Sen, Ronojoy. 2019. Articles of Faith: Religion, Secularism, and the Indian Supreme Court. New Delhi: Oxford University Press.

Shankar, Shylashri. 2018. Secularity and Hinduism's Imaginaries in India. In A Secular Age beyond the West. Edited by Mirjam Künkler, John Madeley and Sjylashri Shankar. Cambridge: Cambridge University Press, pp. 128-51.

Sinha, Bhadra. 2011. SC Takes Back Conversion Remark in Staines Case. Hindustan Times. January 25. Available online: https://www. hindustantimes.com/delhi/sc-takes-back-conversion-remark-in-staines-case/story-WeFdeDep2brkLpgzQ2RGgO.html (accessed on 13 August 2020).

Smith, Samuel. 2019. 8 Christians Arrested in Hindu Mob's Brutal Crackdown on House Churches: Report. ChristianPost. September 28. Available online: https://www.christianpost.com/news/8-christians-arrested-hindu-mob-crackdown-house-churches.html (accessed on 17 April 2021).

Stepan, Alfred. 2001. Religion, Democracy, and the 'Twin Tolerations'. Journal of Democracy 11: 37-57. [CrossRef]

Stepan, Alfred. 2012. Tunisia's Transition and the Twin Tolerations. Journal of Democracy 23: 89-102. [CrossRef]

Taylor, Charles. 2003. Modern Social Imaginaries. Durham: Duke University Press.

United States Commission on International Religious Freedom. 2020. Annual Report 2020. Available online: https://www.uscirf.gov/ sites/default/files/USCIRF\%202020\%20Annual\%20Report_Final_42920.pdf (accessed on 24 May 2021).

Wilkes, Tommy, and Roli Srivastava. 2017. Protests Held across India after Attacks against Muslims. Reuters. June 28. Available online: https:/ /in.reuters.com/article/india-protests/protests-held-across-india-after-attacks-against-muslims-idINKBN19J2C3 (accessed on 9 March 2019).

Zargar, Safwat. 2019. In Kashmir, A Quiet Crackdown-On Mosques and Clerics. Scroll.In. September 6. Available online: https:/ / scroll.in/article/936380/in-kashmir-a-quiet-crackdown-on-mosques-and-clerics (accessed on 10 August 2020). 